\title{
Determinants in Developing a Learning Factory In Higher Educational Institution
}

\author{
Fatimah Mahmud, Puteri Fadzline Mohd Tamyez, Mohamad Farizuan Mohd Nor
}

\begin{abstract}
Manufacturing education will be faced with major challenges in the years to come. Due to the rapid changes of products and production systems, students need to be more exposed to existing and advanced methods. The purpose of this study is to examine a student's perception toward determinants to be considered in developing a learning factory that can provide an authentic industrial working experience in the manufacturing and production sector in the higher educational institution that they are enrolled. An appropriate learning factory experience is expected to improve students' competencies and skills. The study used quantitative method to collect the student perception on determinants of learning factory development. Two hundred questionnaires have been distributed among students of Faculty Industrial Technology Management (FIM) in Universiti Malaysia Pahang (UMP). The results of survey revealed that the most important determinant in developing the learning factory are the learning factory layout design, equipment capability, safety and the effectiveness of assessment given related with theory knowledge that has been learnt. This result is useful for the management of Faculty of Industrial Technology Management to improve their decisionmaking process in enhancing the learning factory in UMP for the future development.
\end{abstract}

Index Terms: Learning Factory, competency, determinant, perception, higher educational institution.

\section{INTRODUCTION}

The higher education institution landscape is undergoing significant changes in order to produce graduates who could be immediately be useful to the industry. According to Kaur and Abdul Manan [1], this change is originating from the "continued with request from student, administration and policy creator for access to a higher share of the population to address the issues of new economies that require an expert and qualified person in today's rapidly expanding globalized working environment". This will help students and management of higher educational institutions to clearly understand and can related between student performance and real life working experiences for future enhancement. Traditional learning method depends essentially on course readings or notes while the modern learning method depends on hands-on materials approach. In traditional methods, introduction of materials begins by focusing on the parts, then proceeds onward to the entire process while in the modern learning approach, introduction of materials begins with the entire, then moves to the parts.

Traditional techniques stress on basis skills while modern strategy underlines on the huge idea. With traditional strategy for educating, appraisal is viewed as a separate activity and happens through testing while with modern technique for learning, evaluation is viewed as an action incorporated with educating and learning, and happens through portfolios and observation [2]. New learning method and systems, for example, dynamic or experiential learning that can possibly improve the education system become an interest to researcher of higher education in university [3][6]. The point of start-up production line factory in Faculty Industrial Management (FIM) is both to present new learning techniques through learning processing in manufacturing industry that identified with the assembling operation and in addition investigating whether innovation uphold learning strategies will add to improved learning impacts of student participation in high-fidelity learning simulation.

\section{A. Learning Factory Concept}

The concept of the Learning Factory has its origins in the medical sciences discipline and specifically, in the paradigm of the teaching hospitals, which aims to incorporate the learning and working environment from which realistic and relevant learning experiences arise [7]. According to Lamancusa et. al., [8], the Learning Factory was created based on three beliefs: lecturing alone is not sufficient; students benefit from interactive hands-on experiences; and experiential, team-based learning involving student, faculty and industrial participation enriches the educational process and provides tangible benefits to all. In order to stimulate the participants' self-organized action and enhance the competencies, Learning Factory thereby integrates different teaching methods with the objective of moving the teaching learning processes closer to real industrial problems. Tisch et.al. [9] combined three different approaches, namely didactic pillar, integrative pillar and engineering pillar [10] Besides that, Nardello et. al. [11] highlighted that the Learning Factory should acts as a platform that enables close collaboration between students, researchers and practitioners.
Revised Manuscript Received on April 25, 2019.

Fatimah Mahmud, Faculty of Industrial Management, Universiti Malaysia Pahang, Kuantan, Pahang, Malaysia.

Puteri Fadzline Mohd Tamyez, Faculty of Industrial Management, Universiti Malaysia Pahang, Kuantan, Pahang, Malaysia.

Mohamad Farizuan Mohd Nor, Faculty of Industrial Management, Universiti Malaysia Pahang, Kuantan, Pahang, Malaysia. 


\section{B. Determinant to be considered on Development of Learning Factory}

With the aim of obtaining full benefits from learning factory development specifically in/at higher educational institutions, there are five determinants have been identified. These determinants are; the setting of learning factory, the experiences of teaching moderator, the equipment provided, the replication of learning factory with real industry and the related theory knowledge toward real practices.

\section{1) Setting of Learning factory.}

The dimension "Setting" describes the represented learning environment and its features [9] Creating a helpful instructive condition is as critical as what is taught and shared [12]. More importantly, it isn't just the framework, the technology, the instructors, or the understudy itself. There is an observation that numerous students are ineffectively arranged and have little idea of the fundamental prerequisites to learn at the advanced education level, including study abilities, inspiration and independence. The continuous improvement philosophy is facilitated by interactive involvement of the participants (students or industrial employees) [13].

\section{2) Experiences of teaching moderator.}

Enhancing student accomplishment is a critical point of any expert learning action. As per Timperley [14], if instructors' expert learning activities are to affect on student results, at that point student results ought to be the focus of that expert learning. Another issue is that instructors might not have the knowledge and skills required to work with student achievement. Parr and Timperley [15] concluded that, with a specific end goal to affect student accomplishment, educators additionally needed educational substance information so they can instruct to address understudies' issues. These issues may raise fascinating outcomes for advanced investigation of the potential results that could reinforced learning environment.

\section{3) Equipment provided.}

Modern undertakings that happen in the learning factory give students the combination of learning encounters into a relevant setting, where accentuation is given to competency and successful application. Prevalent points for teaching factories incorporate vitality effectiveness streamlining and lean administration of generation procedures and techniques. A large portion of the detailed applications of the learning factory worldview mimic the key highlights of a mechanical situation in academic setting, utilizing model generation hardware [16]. A disadvantage of these methodologies is the fact that the committed generation equipment, which is introduced on the academic settings, can soon end up obsolete.
4) Replication of Real Industry.

Universities and training facility are facing with the challenge to distinguish future occupation profiles and connected skill prerequisites and they need to adjust and upgrade their educational concept. Particularly, creative learning situations must have the capacity to respond on previously mentioned challenges. Industry now requests interdisciplinary preparing, which underlines the as of now proven instruction and preparing in learning processing plants. Students can find and test methodologies or direct examinations in this condition on innovative and authoritative industry-related issues [17].

5) Related theory knowledge toward real practices. Instructors in expert or administration related fields would want their students not exclusively to learn theory knowledge and comprehend why speculations are vital yet additionally to figure out how to apply the theory knowledge toward real practices. Over and over again we hear anecdotal records of student in temporary positions who can't make this progress from hypothesis to rehearse with certainty and viability. Maybe the trouble in influencing the change from theory to practice to emerges, in any event to some extent, from a disappointment of the instructor to coordinate both theory and practice into a similar course in the educational programs in ways that are pertinent and important to the student. Such combination encourages students to all the more firmly relate the reasonable benefit of learning theoretical concepts. The subsequent information point to the requirement for a progressing proficient improvement show that direct connects toward training and practices.

\section{METHODOLOGY}

Data for this research was collected using a self-administered survey questionnaire. This survey questionnaire was formulated based on the information obtained from intensive literature review. The instrument was examined using Cronbach Alpha to test the consistency of each item to be assessed in the questionnaire, prior to questionnaire distribution to 200 FIM students. The reliability test indicates that this instrument Cronbach's alpha value is 0.910 . The data obtained from this survey were analysed using Statistical Package for the Science Social (SPSS) software, Version 22.0.

\section{RESULT AND DISCUSSION}

\section{A. Respondents' Demographic}

The number of returned questionnaires that were found to be usable in this study was 148, which represented about $74 \%$ response rate. Most of the responses received were from Third year students (59.5\%), 34.5\% from second year students and only $6 \%$ came from first year students. Majority of the respondents are female $(63.5 \%)$ rather than male $(36.5 \%)$. Meanwhile, more than half $(75 \%)$ of the respondents had experiences using the learning factory and the remaining $25 \%$ does not have the experience and

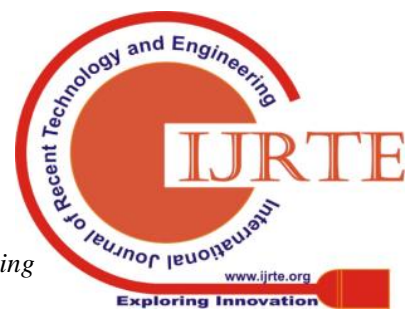


exposure of using the learning factory at FIM. The general background of the respondents involved in this study was summarized in Table 1.

\section{B. Respondents' perception on the Determinants in learning factory development}

This section aims to present the respondents' perception on the determinants that need to be considered in developing the learning factory in educational institution. The respondents were asked to indicate their level of agreement on five identified determinants. Descriptive analysis was used in this study to observe the statistics data of means value. Table 2 shows the mean score for each determinant in developing the learning factory.

Table 1. Respondents' Demographic

\begin{tabular}{|c|c|c|}
\hline & $\begin{array}{l}\text { Number of } \\
\text { respondent }\end{array}$ & $\begin{array}{l}\text { Percentage } \\
(\%)\end{array}$ \\
\hline \multicolumn{3}{|l|}{ Students' Year } \\
\hline $1^{\text {st }}$ Year & 9 & 6 \\
\hline $2^{\text {nd }}$ Year & 51 & 34.5 \\
\hline $3^{\text {rd }}$ Year & 88 & 59.5 \\
\hline \multicolumn{3}{|l|}{ Gender } \\
\hline Male & 54 & 36.5 \\
\hline Female & 94 & 63.5 \\
\hline \multicolumn{3}{|l|}{ Race } \\
\hline Malay & 106 & 71.6 \\
\hline Chinese & 37 & 25 \\
\hline Indian & 5 & 3.4 \\
\hline $\begin{array}{l}\text { Experienced } \\
\text { learning factory }\end{array}$ & using & \\
\hline Yes & 111 & 75 \\
\hline No & 37 & 25 \\
\hline
\end{tabular}

Table 2. Determinants for Learning Factory Development

\begin{tabular}{lcc}
\multicolumn{1}{c}{ Determinant } & $\begin{array}{c}\text { Mean } \\
\text { score }\end{array}$ & Ranking \\
\hline $\begin{array}{l}\text { Setting of Learning Factory } \\
\begin{array}{l}\text { Experiences of teaching } \\
\text { moderator }\end{array}\end{array}$ & 4.56 & 1 \\
$\begin{array}{l}\text { Equipment provided } \\
\text { Replication of Real Industry }\end{array}$ & 4.40 & 3 \\
$\begin{array}{l}\text { Related theory knowledge } \\
\text { toward real practices }\end{array}$ & 4.30 & 5 \\
\hline
\end{tabular}

Based on Table 2, the respondents' perceived that the setting of learning factory (4.56), the replication of real industry (4.50) and the experience of teaching moderator (4.40) are the three most important determinants that need to be considered in developing the learning factory in educational institution. They felt that learning factory with an effective layout, clean and good arrangement of materials will provide conducive learning environment. Subsequently, increase student understanding, reduce time spent to perform task and improve their performance and technical skills. These findings support Lamancusa et. al., [8], where it is mentioned that the right environment will motivate students to learn on their own and their personal experience on real problems develops skills and knowledge that are far more memorable and transferable than a passive lecture.

Regarding the experiences of teaching moderator as one of the highest determinant in learning factory development, the respondent opined that besides the adequate experiences on manufacturing industry, the teaching moderator should have the ability to encourage effective two-way communication between moderator and student and facilitate them to participate in problem solving activity. Respondents demonstrated a high agreement on the equipment provided in learning factory. The essential elements of learning factory are to have a sufficient and good condition equipment. In order to complete the learning factory design, the educational level and the technological infrastructure must be aligned, safe, multi-disciplinary, well-equipped, general purpose, welcoming, and visually impressive [18; 8].

Development of learning factory should replicate the real industry is one of the highest mean score determinant in this research. By providing the machine and equipment that has been used in the real industry workplace will give the exposure to the students to familiarize with those equipment, improve their technical skills and increase their readiness to adapt with future workplace environment. Moreover, this research finding indicate that the respondents are concerned on the safety of the learning factory layout, equipment and operations. Student always adhere a safety instruction in order to avoid any incident that will affect both themselves and university reputation. Meanwhile, the respondent highlighted the related knowledge towards real practice should be given and embedded in subject taught at university. This is important to prepare the students with needed skills (i.e. managerial, problem solving and other soft skills) and to face the real challenges at the workplace.

\section{CONCLUSION}

As a conclusion, the respondents agreed that all the identified determinants are crucial to be considered in developing a learning factory in higher educational institution. By transforming the learning method to the usage of learning factory, this will enhance the students' understanding on the subject taught, improve their skills and competency level and increase their readiness and confidence to work in the industry.

The collaboration and feedback from the industry seems to be an effective way to continuously enhance the developed learning factory. The study findings provide a useful input specifically to the Faculty Industrial Management to continuously improve and enhance thende Existing learning factory and generally for UMP to povide the finding for learning factory development. It พᄁָํ. 
other educational institutions to consider all the determinants to develop their learning factory. Future research could scrutinize the impact of the learning factory usage to the student performance based on different program outcome attainment.
18. M. Tisch, C. Hertle, J. Cachay and E. Abele, "A Systematic Approach On Developing Action-Oriented, Competency-Based Learning Factories", Procedia CIRP, vol. 7, pp. 580-585, 2013.

\section{ACKNOWLEDGMENT}

The researchers wish to thank Research and Innovation Department, Universiti Malaysia Pahang (UMP) for funding the conduct of this research through RDU 1603135. The researchers also appreciate the support and commitment from all UMP students who participated in the survey and provided useful responses.

\section{REFERENCES}

1. S. Kaur and S. M. Abdul, "The Learning Experiences of postgraduate students: Emergent themes." In Z. Moris, H. Abdul Rahim \& S. Abdul Manan (Eds.). Higher Education in the Asia Pacific: Emerging trends in teaching and learning 14-33. 2008, Penang: IPPTN and Universiti Sains Malaysia Press.

2. M.G. Brooks and J.G. Brooks, The courage to be constructivist, 1999 , Educational Leadership (3) Retrieved October 2, 2015.

3. K.H. Lee, "Chocolate Chip Cookies as a Teaching Aid", The American Statistician, vol. 61, pp. 351-355, 2007.

4. M. Barak, A. Lipson and S. Lerman, "Wireless Laptops as Means for Promoting Active Learning in Large Lecture Halls", Journal of Research on Technology in Education, vol. 38, pp. 245-263, 2006.

5. J. D. Hansen, "Using Problem-Based Learning in Accounting", Journal of Education for Business, vol. 81, pp. 221-224, 2006.

6. J. A. Raelin, and D. Coghlan, "Developing managers as learners and researchers: using action learning and research", Journal of Management Education, vol. 30, pp. 670-689, 2006.

7. G. Chryssolouris, D. Mavrikios and L. Rentzos, "The Teaching Factory: A Manufacturing Education Paradigm", In 49th CIRP Conference on Manufacturing Systems, Procedia CIRP, vol. 57, pp. 44-48, 2016.

8. J. Lamancusa, J. Zayas, A.L. Soyster, L. Morell and J. Jorgensen, "The Learning Factory: Industry-Partnered Active Learning", Journal of Engineering Education, vol. 97, no. 1, pp. 5-11, 2008.

9. M. Tisch, F. Ranz and J. Metternıch, "Learning Factory Morphology Study of Form and Structure of an Innovative Learning Approach in The Manufacturing Domain", The Turkish Online Journal of Educational Technology, vol. 2, 356-363, 2015.

10. F. Baena, A. Guarin, J. Mora, J. Sauza and S. Retat, "Learning Factory: The Path to Industry 4.0", In 7th Conference on Learning Factories, CLF 2017 Procedia Manufacturing, vol. 9, pp. 73 - 80, 2017.

11. M. Nardello, O. Madsen and C. Møller, "The Smart Production Laboratory: A Learning Factory for Industry 4.0 Concepts." CEUR Workshop Proc, vol. 1898, pp. 1-5, 2017.

12. S. K. Kwa, "Medical Education Notes for the Primary Care Teachers, How do adults learn?" Malaysian Family Physician, vol. 2, no. 1, pp. 25-26, 2017.

13. I. Veeza, N. Gjeldum, M. Mladineo, S. Celar, I. Peko, M. Cotic, P. Ljumovic and Z. Stojkic, "Development of Assembly Systems in Lean Learning Factory at the University of Split", In 7th Conference on Learning Factories, CLF 2017 Procedia Manufacturing, vol. 9, pp. 49-56, 2017.

14. H.S. Timperley, "Teacher professional learning and development", Belley, France: International Academy of Education, 2008.

15. J. Parr, Mand, H.S. Timperley, "Teachers, schools and using evidence: Considerations of preparedness". Assessment in Education: Principles, Policy and Practice, vol. 15, pp. 57-71, 2008.

16. U. Wagner, T..Al Geddawy, H. El Maraghy and E. Müller, "The State-of the- Art and Prospects of Learning Factories", Procedia CIRP, vol. 3, pp. 109-112, 2012.

17. E. Abele, J. Metternich, M. Tisch, G. Chryssolouris, W. Sihn and H. El Maraghy, "Learning Factories for Research, Education, and Training", In: Procedia CIRP, vol. 32, pp. 1-6, 2015. 